Peer-reviewed

\title{
Situational Awareness and Current Information Environment
}

\section{Znalost situace a současné informační prostředí}

\section{Marek Fiebich}

Abstract: The article deals with providing situational awareness in operations at the operational level of command in the context of the information environment, the current nature of which significantly affects the execution of this capability. It examines the influence of three selected aspects information overload, the expansion of advanced information technology and the growing importance of the cyber domain - on generating, maintaining and sharing situational awareness in planning and conduct of operations. It identifies and characterizes the respective sub-capabilities within the information area, necessary for operational headquarters to effectively provide situational awareness, and outline possible ways to develop these capabilities in terms of internal processes, technical equipment and personnel.

Abstrakt: CClánek pojednává o zajištování znalosti situace v operacích na operační úrovni velení a řízení v kontextu informačního prostředí, jehož současný charakter zásadním způsobem realizaci této schopnosti ovlivňuje. Zkoumá vliv tří vybraných aspektů - informačního zahlcení, rozmachu pokročilých informačních technologií a rostoucího významu kybernetické domény na utváření, udržování a sdílení znalosti situace při plánování a vedení operací. Identifikuje a charakterizuje odpovídající dílčí schopnosti v rámci informační oblasti, kterými musí operační velitelství disponovat k účinnému zajištování znalosti situace, a nastínit možný způsob rozvoje těchto schopností z pohledu vnitřních procesů, technického vybavení a personálu.

Key words: Situational Awareness; Operating Environment; Information Environment; Cyberspace.

Klíčová slova: Znalost situace; operační prostředí; informační prostředí; kyberprostor. 


\section{INTRODUCTION}

The current complex and dynamic nature of the operating environment places high demands on the armed forces and their development within a large spectrum of activities. One of these activities is also generating and maintaining situational awareness in the battlefield, which is essential for successful planning and conduct of operations. Moreover, the importance of this capability will continue to grow in connection with future operations, which will be conducted across operational domains ${ }^{1}$, and for the coordination of which a thorough knowledge of the situation will be one of the decisive factors. With regard to the nature of the current operating environment and the aspects of situational awareness, it can be argued that it is the developments within the information environment that influence this capability the most. That is also why a considerable importance is being attached to the information environment in relation to situational awareness in current and future operations:

"Good situational awareness of all levels of the deployed forces is crucial for [European Union] Member States' militaries to gain and maintain advantages over the adversaries of 2035 and beyond. This will require an acknowledgement of the increasing importance of understanding the information environment..."

It is practically impossible to provide comprehensive situational awareness in today's operating environment without advanced information technology to process an enormous amount of information, the ability to effectively control this technology or a large information infrastructure enabling prompt and secure sharing with all participants of an operation at all levels of command. Moreover, cyberspace, as a subset of the information environment, has itself become part of the battlefield, and the information acquired from and on it is becoming an integral part of situational awareness, which is thus taking on completely new dimensions. In order for the headquarters to be able to generate and maintain thorough situational awareness in such an environment, appropriate efforts reflecting the latest developments of the information environment and its aspects must be taken to develop existing and build new capacities and functions to support this crucial command and control capability. This applies particularly at the operational level where the execution of this capability seems to be most problematic. Operational headquarters face an enormous amount of information flowing from an increasingly dynamic tactical level, an increasing range of aspects that must be addressed through a joint effort; all while being coordinated by the strategic level within the comprehensive approach.

1 Air, land, maritime, space and cyberspace.

2 KEPE, Marta, James BLACK, Jack MELLING and Jessica PLUMRIDGE. Exploring Europe's capability requirements for 2035 and beyond: Insights from the 2018 update of the long-term strand of the Capability Development Plan. Brussels: European Defence Agency, 2018, p. 22. 


\section{SITUATIONAL AWARENESS}

\subsection{Definition of situational awareness}

Within NATO, situational awareness is defined as "the knowledge of the elements in the battlespace necessary to make well-informed decisions." 3 Although this definition, providing only a general framing of the term, may be adequate with regards to its purpose of Allied standardization, it does not provide the necessary appreciation of the nature and the scope of situational awareness.

To define the term in more detail, it seems appropriate to use the definition of M. R. Endsley, which arose from an American research project within military aviation and became the underlying definition of situational awareness in many disciplines (from civil aviation to engineering to medicine or psychology). Although her concept is also used for defining situational awareness in the NATO Consultation, Command and Control Board taxonomy ${ }^{4}$, it has surprisingly not been included in NATO's official definition. Endsley defines situational awareness as "the perception of the elements in the environment within a volume of time and space, the comprehension of their meaning, and the projection of their status in the near future." 5 The main benefit of this definition - and a significant difference from NATO's official definition - is that it divides situational awareness into three successive phases (levels) that must be reached to achieve thorough knowledge, thereby covering all important aspects of situational awareness:

1) The perception of elements in the environment in time and space represents the ability to perceive the status, characteristics and dynamics of relevant elements of this environment.

2) The comprehension of the current situation is based on a synthesis of individual elements of the environment. It is not mere awareness of the elements in the environment, but the ability to understand the environment as a whole, with all its (relevant) elements and the significance of these elements.

3) Based on knowledge of the status and dynamics of the elements (Phase 1) and subsequent understanding of the situation (Phase 2), it is possible to achieve the ability to project, that means to some extent the ability to predict, possible activities of elements in the environment in the near future. Only at this stage does

3 AAP-6, Edition 2019, NATO Glossary of Terms and Definitions (English and French). Brussels: NATO Standardization Office, 2019, p. 118.

4 C3 Taxonomy Perspective, Baseline 2. 0. 2015. Brussels: NATO Consultation, Command and Control Board.

5 ENDSLEY, Mica R. Toward a Theory of Situation Awareness in Dynamic Systems. Human Factors: The Journal of the Human Factors and Ergonomics Society [online]. 1995, 37(1), 32-64 [cit. 2020-03-12]. ISSN 0018-7208. Available at: http://journals.sagepub.com/doi/10.1518/001872095779049543, p. 36. 
situational awareness gain the added value necessary to support the decision-making process. ${ }^{6}$

To demonstrate the process in the deployed headquarters settings, enemy or own units, their location, size, capabilities or activities in the area of operations, as well as civilian gatherings and incidents or events in the area are good examples of the perceived elements in the environment (Phase 1). Understanding the situation (Phase 2) would then mean to realize that the activities of particular enemy units can, in relation to activities of its other forces, or of own forces, indicate the enemy's intentions. Similarly, local gatherings may be a response to an incident that has occurred within (or even outside) the area of operations. Completing these two phases then allows the staff or the task force commander to assume (Phase 3 ) that and how the enemy plans to attack, as well as to assume that the mood of the crowd and the entire local population may grow into aggression provided that the consequences of the incident are not dealt with.

In the context of conduct of operations, using both of the above-mentioned definitions, and for the purposes of this article, situational awareness can best be defined as "the knowledge of the elements in the battlefield based on the perception of these elements in time and space, comprehension of their meaning and projection of their status in the near future, and created and maintained to support the well-informed decision-making in operations."

\subsection{Situational awareness in terms of its users}

In general, situational awareness is seen as the knowledge of an individual. This individual knowledge, however, can be used to contribute to the knowledge of a group that the individual is a part of, to the benefit of an organization. ${ }^{7}$ Thus, although we can, in relation to the conduct of military operations, refer to situational awareness as the knowledge of each staff member or the commander, situational awareness is in this respect most often understood as group knowledge. This group knowledge is provided by the operations centre as a whole (a group) in terms of a product for the benefit of the commander and the entire headquarters (an organization). At the operational level, this group is represented by the Joint Operations Centre (JOC), or the Combined Joint Operations Centre (CJOC), which is responsible for generating and maintaining situational awareness of the Joint Task Force headquarters (JTF HQ).

Situational awareness created within a given headquarters, which is distributed outside this headquarters, is referred to as "shared situational awareness". Its purpose is to ensure that all entities (individual subordinate headquarters, partner units, non-military

6 Ibid, p. 36-37.

7 CANAN, Mustafa and Bulent SOYKAN. Shared Situational Awareness / Understanding: A Key Attribute of Mission Command Concept for NATO. In: 21st ICCRTS: C2 in a Complex Connected Battlespace [online]. London. [cit. 2020-03-23]. Available at: https://www.researchgate.net/publication/307923119_Shared_ Situational_Awareness_Understanding_A_Key_Attribute_of_Mission_Command_Concept_for_NATO. 
actors and other elements) participating in the operation in all affected domains have the same up-to-date knowledge in support of well-informed decision-making and effective synchronization of the joint effort. The relationship of these individual "types" of situational awareness generated within the JTF HQ is schematically depicted in Figure 1.

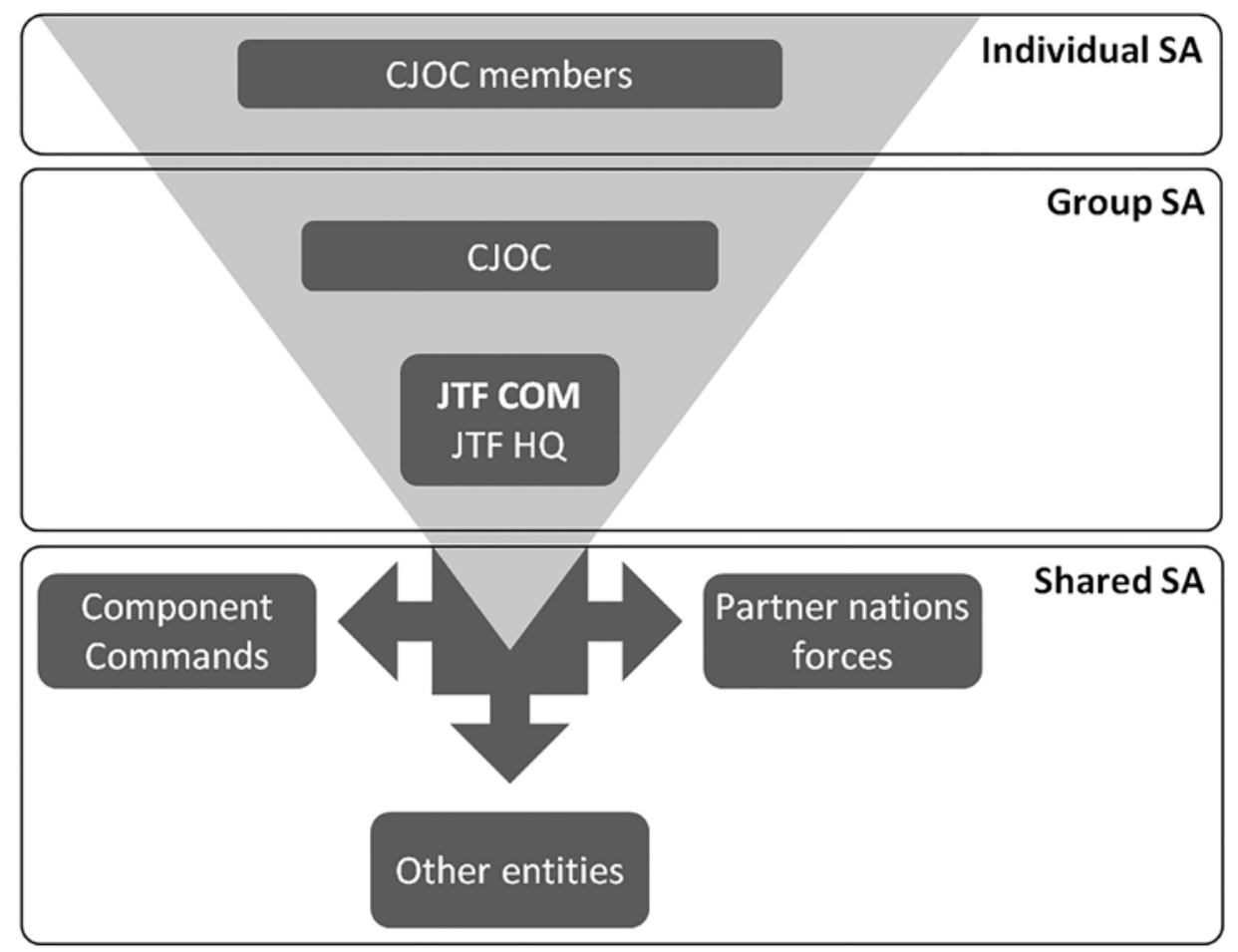

Figure 1: Individual, group and shared situational awareness 


\section{SELECTED ASPECTS OF THE CURRENT INFORMATION ENVIRONMENT}

The expansion of the information environment ${ }^{8}$ and particularly the advances of the information technology, which "have increased the speed and range of information, diffused power over information, and shifted socio-cultural norms," 9 fundamentally affect all aspects of operations, including situational awareness. The possibility (and capability), through advanced information technology, to collect a wide range of information from a variety of sources on all aspects of the operating environment, transmit this information promptly to the headquarters often located far away from the battlefield, transform it into concise yet thorough information products, and distribute these promptly within and outside the headquarters, provides an invaluable knowledge support to the decision-making process in planning and conduct of operations within the complex and dynamic operating environment.

\subsection{Information overload}

However, the immediate access to a large amount of information from the operating environment does not guarantee better situational awareness, nor does it guarantee better decision-making. Often the opposite is true. The extensive amount of easily accessible information represents for the headquarters of the deployed forces, and mainly their operational centres that serve as information gateways to these headquarters, a significant challenge or even an obstacle to successful operations. Thus, while in the past the main problem related to the decision-making process in operations was the lack of information, now the problem lies in the excessive amount of information. The need to process every piece of available information, analyse only the information that is relevant to the operation and distribute it to those (and only those) elements of the headquarters, units and other entities that necessarily need this information for their decision-making, this brings a number of negative consequences.

The main drawback related to the enormous amount of information is information overload associated with the difficulty of "finding, within the mass of data available,

8 The NATO Allied Joint Doctrine for the Conduct of Operations defines the information environment as "a composite of the information itself, the individuals, organizations and systems that receive, process and convey the information, and the cognitive, virtual and physical space in which this occurs." (See Allied Joint Publication-3. Allied Joint Doctrine for the Conduct of Operations. AJP-3. 2019. Brussels: NATO Standardization Office, LEX-6).

9 Joint Concept for Operating in the Information Environment (JCOIE).

2018. Washington, D.C.: Joint Chiefs of Staff, p. vii. 
those precise bits of information that are needed to make an informed, reasoned decision." ${ }^{10}$ Although it is the members of the operations centre, which serves as an information hub responsible for the entire "operational" information management, that struggle with this issue the most, information overload does not only concern the initial recipients of the information. In fact, every staff member and also the commander can be overloaded with information, and this often really is the case. As the input grows, so does the amount of information and information products further distributed to the commander, staff and entities outside the headquarters, thus spreading information overload across headquarters and the deployed forces. This very often prevents these subsequent recipients from understanding the complex situation in the battlefield thoroughly and making the necessary well-informed decisions. Additionally, the information systems of the given operations centre or the entire headquarters may also be overwhelmed with the enormous information flow, disabling the systems temporarily or even permanently.

Information overload can thus hamper the provision of situational awareness, the execution of command and control as well as the entire operation. As Cochran and Shaw put it, "information overload creates analysis paralysis and ultimately impacts efficient tactical, operational and strategic operations." ${ }^{11}$ In order to avoid paralyzing the information analysis, a robust information infrastructure must be established and suitably set up within the headquarters, in addition to proper Information Management (IM) processes, which will enable the staff to handle the enormous amount of information both effectively and efficiently.

\subsection{ADVANCED INFORMATION TECHNOLOGY}

Given the nature of the current operating environment and the scale of operations to be conducted, generating and maintaining situational awareness would be practically impossible without the use of advanced information technology tools and systems, and these need to be a regular part of every operational headquarters of the deployed forces. Moreover, their role will increase even more in future operations. As Reilly puts

10 STRATER, Laura, FAULKNER, Laurie, HYATT, John, ENDSLEY, Mica. Supporting Situation Awareness Under Data Overload in Command and Control Visualizations. 2006. [cit. 2020-03-12]. Available at: https://www.researchgate.net/publication/252218394_Supporting_Situation_ Awareness_Under_Data_Overload_in_Command_and_Control_Visualizations, p. 2.

11 COCHRAN, John and Michael SHAW. Mission Command as Applied by US Army - Aviation Perspective. In: NATO COMMAND \& CONTROL CENTRE OF EXCELLENCE SEMINAR: C2 ON THE MOVE. [online]. 2015, Den Helder, p. 64-69. [cit. 2020-03-17]. Available at: https://c2coe.org/download/c2-on-the-move-seminar/, p. 68. 
it, global proliferation of advanced information technology is the principal factor driving the so-called multi-domain operations. ${ }^{12}$

An important role in situational awareness, and the conduct of operations in general, is played by the growing integration of commercial aspects into the military field, such as the Internet of Things or the so-called commercial off-the-shelf products, ranging from social media-based platforms ${ }^{13}$ to complex software and hardware solutions to transmit, process and visualize data from the battlefield at all levels of command. Another example of indispensable information technology, usually provided by the commercial sphe$\mathrm{re}$, is the software designed to analyse so-called big data ${ }^{14}$. Without big data analytics, providing accurate situational awareness during current and future operations would be practically impossible. The big data analytics allows "examining massive data sets containing a variety of data types to uncover hidden patterns, correlations and other strategic business and operational information"15 related to the situation in the battlefield, and thus "may help the commander pursue understanding, to overcome the risk of information overload." 16

With a further increase of the amount of information and the interrelationship of information with all other elements of the operating environment, the importance of the big data analytics capability will continue to grow accordingly. The British Ministry of Defence anticipates that the operating environment actors, including non-state actors, will make a significant effort in the coming years to build the big data analytics capability to gain information superiority. ${ }^{17}$ As a result "language processing, anomaly detection and visualisation tools will be far more prevalent and will identify activities and trends much earlier than conventional techniques. ${ }^{\prime 18}$ The big data analytics, as well as a number of other information technology capabilities, is thus likely to join other areas in which the differences in capabilities between actors with greater combat potential and those with lower combat potential are being diminished, or in which a reverse difference is being created in favour of the otherwise weaker actors. In situations where actors possess the same or similar resources, it is necessary, in order to achieve dominance, to focus on developing those capabilities that will leverage the effects of such resources. In the case of achieving information superiority to support the provision of situational awareness with

12 REILLY, Jeffrey. Multi-Domain Operations. In: Joint Air \& Space Power Conference 2019: Shaping NATO for Multi-Domain Operations of the Future [online]. 2019, Kalkar: Joint Air Power Competence Centre, p. 15-24. [cit. 2020-04-02]. Available at: https://www.japcc.org/wp-content/uploads/JAPCC_Read_ Ahead_2019.pdf.

13 See FORRESTER, Bruce. Integrating Social Media Tools with Command and Control (C2): What are the Possibilities? [online]. 2016, Québec. Available at: https://cradpdf.drdc-rddc.gc.ca/PDFS/unc229/ p803913_A1b.pdf. Scientific Report. DRDC - Valcartier Research Centre.

14 Velká data (big data) Ize chápat jako objem dat, který vzhledem $\mathrm{k}$ jeho velikosti není možné přijímat, zpracovávat, ukládat a analyzovat běžnými databázovými nástroji.

15 FABER, Isaac and Ellisa ZADROZNY. OPEN SOURCE BIG DATA. ARMY AL \& T [online]. 2016, 56(3), 104-109 [cit. 2020-03-12]. Available at: https://asc.army.mil/docs/magazine2/armyalt-jul-sep-2016.pdf, p. 105.

16 Future Operating Environment 2035. 2015. London: Ministry of Defence UK, p. 42.

17 Future Operating Environment 2035. 2015. 1. London: Ministry of Defence UK.

18 Ibid UK, p. 19. 
similarly advanced information technology, increasing the skills of personnel who work with these systems to process the information from the battlefield seems to be the most effective way. The last chapter of this article elaborates on this issue further, offering specific aspect of personnel development to focus on.

\subsection{Information security in cyberspace}

Another aspect also inherently connected with the dynamic development of the information environment and particularly the information technology is the increased need to protect information within cyberspace. Information, being most vulnerable when being processed and transmitted, needs to be protected from potential cyber threats as well as technical failure. ${ }^{19}$ Insufficient protection of information, especially in the context of shared situational awareness, can, in case of damage or theft of this information, deprive the headquarters of the information advantage or provide the enemy with information on current or planned activities of own forces and thus jeopardize the security of this forces or threaten the success of the entire operation.

The need for information and network protection increases with respect to the aforementioned growing share of the Internet of Things and commercial products in the conduct of operations. As Fučík et al. point out, although the complex interconnection of the systems in cyberspace allows, among others, for real-time decision-making (contingent on achieving real-time situational awareness), it also "deepens the overall dependence on a stable and effective operation of this area, "20 which places high demands on ensuring security in cyberspace. Measures to ensure the resilience of networks and information security in generating and sharing situational awareness (especially when distributed outside the information system of the headquarters) must then be one of the main priorities for the operation to be successful. This implies that, for example, a thorough examination of the credibility and reliability needs to be conducted in relation to the integration of commercial deployable information systems to maintain the integrity of the transmitted data. ${ }^{21}$

19 LEEVINSON, J., V. VIJAYARAGHAVAN and M. DAMMODARAN. Blockchain Mechanisms as Security-Enabler for Industrial IoT Applications. MAHMOOD, Zaigham, ed. The Internet of Things in the Industrial Sector: Security and Device Connectivity, Smart Environments, and Industry 4. 0. Cham: Springer, 2019, s. 145162. ISBN 978-3-030-24891-8.

20 FUČík, Jakub, Fabian BAXA, Libor FRANK and Josef PROCHÁZKA. 2019. Technological Development: The Implications for the Capabilities of the Armed Forces of the Czech Republic 2018. 1. Brno: University of Defence in Brno, 24 p., p. 9.

21 WRONA, Konrad. 2015. Securing the Internet of Things a military perspective. In: 2015 IEEE 2nd World Forum on Internet of Things (WF-IOT) [online]. Milan, p. 502-507. Available at: https://ieeexplore.ieee. org/document/7389105. 


\section{INFORMATION ENVIRONEMT AND SHARED SITUATIONAL AWARENESS}

To serve its purpose of supporting decision-making, situational awareness generated during the operation has to be shared by all who need to make decisions based on it within that operation. This need increases in complex operations involving a large number of diverse task forces and entities, such as in the multi-domain operations. Within the U.S. Armed Forces "Multi-Domain Operations" concept, shared situational awareness is, together with an adequate effort to exercise these multi-domain activities and the coordination of synchronic operations, considered as one of the critical conditions that the forces of participating states have to meet to successfully conduct these operations. ${ }^{22}$ A research conducted for the European Defence Agency puts the "efficient information sharing with joint multinational forces and with other military and civilian actors on the ground..." 23 to the role of an underlying requirement of all main military capabilities. Similarly to generating and maintaining situational awareness, it will be necessary to face the challenges that result from the nature of the information environment, mainly in the form of growing amount of information available, keeping pace with the ongoing advancement of information technology, and meeting the demands for prompt (immediate) information sharing.

More than ever before, the selection and the level of detail of information shared across the entities involved in the operation are essential to handle the increased amount of information. The fact that information is shared does not alone guarantee organization's better knowledge of the situation. Although it is the purpose of shared situational awareness to ensure a common understanding of the situation in the battlefield across the entities involved in the operation, it is substantially counterproductive for everyone to be informed of everything as it wide-spreads information overload. As an experiment conducted at a joint task force headquarters during a large-scale military exercise of the U.S. Army demonstrates, during which the entire operational communication of the whole headquarters was monitored, once the amount of information shared reached a certain threshold, the knowledge of the situation in the battlefield of the staff began to decrease from that moment on. ${ }^{24}$ In rare occasions is this phenomenon caused by a faulty configuration of information systems that process the shared information. In most cases it is the human failure error, nourished by the information overload that causes such situations, in the form of mass information distribution or faulty attribution,

22 WATLING, Jack and Daniel ROPER. 2019. European Allies in US Multi-Domain Operations. RUSI Occasional Paper. London: Royal United Services Institute, p. 14.

23 KEPE, Marta, James BLACK, Jack MELLING a Jessica PLUMRIDGE. Exploring Europe's capability requirements for 2035 and beyond: Insights from the 2018 update of the long-term strand of the Capability Development Plan. Brussels: European Defence Agency, 2018, p. 21.

24 BUCHLER, Norbou, Sean FITZHUGH, Laura MARUSICH, Diane UNGVARSKY, Christian LEBIERE and Cleotilde GONZALEZ. 2016. Mission Command in the Age of Network-Enabled Operations: Social Network Analysis of Information Sharing and Situation Awareness. Frontiers in Psychology [online]. 7:937. Available at: https://www.frontiersin.org/articles/10.3389/fpsyg.2016.00937/full. 
in which operational attributes are assigned to the information or information product and distributed accordingly. As a result, such information then may be dealt with by personnel that do not need it, or reversely, the personnel that actually need it do not receive it. In both cases, decision-making of the respective personnel related to the operation can be affected.

\section{COMMON OPERATIONAL PICTURE}

The common operational picture (COP), as an essential "product" generated for the purpose of providing both the group and shared situational awareness, is the main platform enabling the visualization of situational awareness and its sharing with other users. In NATO, this function is conveyed by the NATO Common Operational Picture (NCOP) system, which is able to process and include in the overall picture information from a number of systems used by component commands, member states and other entities if appropriate. In order for this (or any other similar) system to be able to act as "a single authoritative source of data which reflects the needs of commanders and staffs" 25 during operations in the current and future operating environment, its capabilities must necessarily reflect current developments in the information environment.

\subsection{Real-time common operational picture}

As a result of the dynamic developments throughout the entire operating environment, also the demand for developing the capability of real-time decision-making is also growing. Reaching this capability is conditioned, among other things, by the capability to provide real-time situational awareness. In response to this demand, the common operational picture systems get augmented with additional products and service such as applications to visualize the situation to be used in cell phones or tablets. These mobile applications are now being implemented within modern armed forces, predominantly at the tactical level, allowing for immediate sharing of information from the battlefield between individuals and units in the field and their respective tactical operations centres, and thus supporting real-time decision-making significantly. Immediate access to information from the tactical level, rapid development of the situation in the battlefield and the need to coordinate activities across domains stimulate the demand for real-time (or rather near real-time) decision-making (and situational awareness) at the operational level as well.

25 FORRESTER, Bruce. 2016. Integrating Social Media Tools with Command and Control (C2): What are the Possibilities? [online]. Québec. Available at: https://cradpdf.drdc-rddc.gc.ca/PDFS/unc229/ p803913_ A1b.pdf. Scientific Report. DRDC - Valcartier Research Centre, p. 29. 
The mobile common operational picture will allow the staff members and especially the commander of the operational headquarters to maintain the knowledge of the situation in the battlefield and to make respective decisions, when appropriate, even when distant from the joint operations centre or their workplaces. As a result, the joint operations centre as a central information hub located in a large room with dozens of screens as known today, may soon not the case anymore.

The integration of the mobile operational picture, the large amount of information and frequent incorrect selection of information to be shared through the common operational picture again creates the issue of a negative impact on understanding the situation by the staff and mainly the commander. With a certain degree of simplification, it can be said that not all information should be placed on the map, because too much information not only reduces the lucidity of the picture, but more importantly, it also may prevent the commander from understanding the situation it depicts. ${ }^{26}$ Although the common operational picture allows the "map" to be customized by filtering the information displayed, a judicious selection of information (based on its relevancy and in consideration of the developments in the battlefield) to be included in the common operational picture is necessary.

\subsection{Cyber common operational picture}

The fact that cyberspace is no longer treated only as a space through which information is being transferred but also became a part of the battlefield in which operations are being conducted, has great implications within situational awareness, as this creates the need for a recognised cyber picture to be generated and incorporated into the common operational picture. Not only will this provide situational awareness in cyber operations, but it will also contribute to the effective coordination of the joint effort in future operations across domains.

In relation to generating the common operational picture, Radabaugh points to the difficult task of appropriate visualisation of cyberspace in a way that will allow it to be perceived it the same way as the air, land, maritime and space battlefields. Only in this way, according to him, will it be possible to achieve an effective integration of information and traditional physical force, necessary to conduct operations across domains. ${ }^{27}$ However, the question of the technical complexity of the appropriate visualization of the recognised cyber picture, and its incorporation into the common operational pictu$\mathrm{re}$, is only one of the possible complications in achieving effective integration of cyber warfare into "traditional" warfare. As Conti, Nelson and Raymond emphasise, not only

26 PAUL, Christopher, Colin P. CLARKE, Bonnie L. TRIEZENBERG, David MANHEIM and Bradley WILSON. 2018. Improving C2 and Situational Awareness for Operations in and Through the Information Environment. Santa Monica: RAND Corporation.

27 RADABAUGH, Gregory C. 2018. The Practical Implications of Information as a Joint Function. Joint Force Quarterly. 89(2), 15-17. 
will cyber support be provided, in some cases, by originally "non-cyber" staff without in-depth knowledge and experience in cyber warfare, but the recognised cyber picture (although simplified) will also be provided to commanders and staff with minimal or no knowledge and experience in such a technically oriented area. ${ }^{\mathbf{2 8}}$ Initially, this will prevent them from understanding the cyber situation and from acquiring thorough knowledge of the joint situation in the battlefield within all domains. Therefore, it can be expected that, in order to create conditions for a full integration into the common operational picture, cyber situational awareness will initially be provided either separately (that is only in cyberspace) without the need for being interconnected with other pictures, or only in limited support of the common operational picture.

\section{DEVELOPING STAFF SKILLS TO PROVIDE SITUATIONAL AWARENESS}

Constant advancement of information technology and its increasing integration into military operations places high demands on personnel with respect to their ability to work effectively with the increasingly complex and technically demanding means to process, evaluate, analyse and share information, and these skills have to be permanently and actively developed. The need to enhance the skills of the staff in this field is also closely connected to the already mentioned phenomenon of gradual diminishing of differences in the information technology capacities possessed by the actors. According to Endsley, however, "the challenges are not simply in learning to physically perform a task and mastering the motor skills required for performance, but rather in perceptual and cognitive task mastery. ${ }^{29}$ In other words, despite the need for training and subsequent practice in using respective tools and systems, it is necessary, with regard to the enormous information burden, to develop the perception and cognitive functions of the staff, such as memory, concentration, logical reasoning, problem-solving, speed of information processing or the ability of expression.

The way these functions are involved in the process of generating situational awareness can be demonstrated on Endsley's model, which captures situational awareness within the decision-making process (Figure 2). The system factors (depicted in the upper part of the figure) represent those characteristics and means that can be assumed to be available to all actors. In the case of the operational headquarters, or its joint operations centre, its hardware and software used to collect, process and analyse information is an

28 CONTI, Gregory, Robert FANELLI, David RAYMOND and John NELSON. 2013. Towards a Cyber Common Operating Picture. In: 2013 5th International Conference on Cyber Conflict: Proceedings [online]. Tallinn: NATO CCD COE Publications, p. 279-295. Available at: https://ccdcoe.org/uploads/2018/10/CyCon_2013_ Proceedings.pdf.

29 STRATER, Laura, FAULKNER, Laurie, HYATT, John, ENDSLEY, Mica. Supporting Situation Awareness Under Data Overload in Command and Control Visualizations. Available at: https://www.researchgate.net/ publication/252218394_Supporting_Situation_Awareness_Under_Data_Overload_in_Command_and_ Control_Visualizations, p. 1. 
example of such factors. Although there are also qualitative developments on the side of the system factors, it is unlikely, given the above-mentioned trend of capacity convergence of actors, that predominance will be achieved in this area. On the other hand, the individual factors, that is the factors on the part of an individual or a group, are mainly comprised of the cognitive functions and experience mentioned (indicated by the bold line in the lower part of the figure). These need to be developed by each actor as they cannot be acquired otherwise (for example, to be purchased), as is the case with most system factor. The possibility of achieving dominance is thus limited only by human potential and the efforts made to utilise this potential.

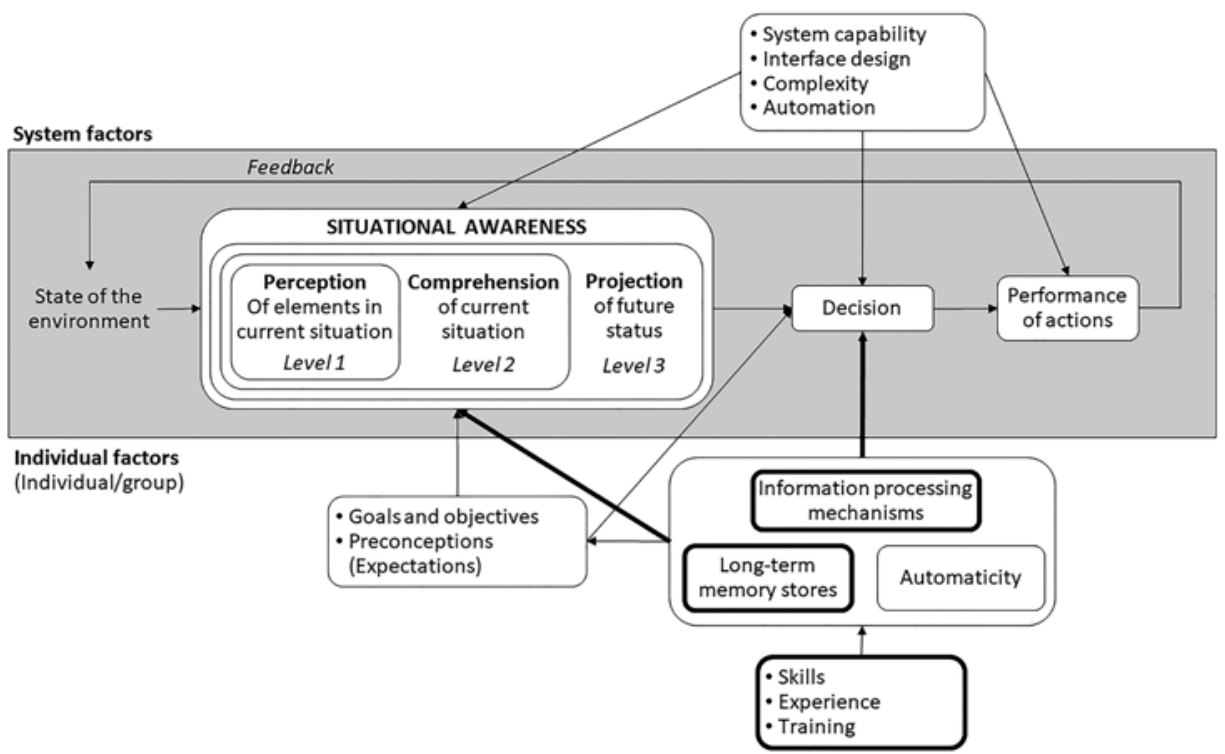

Figure 2: Factors affecting situational awareness and decision-making ${ }^{\mathbf{3 0}}$

In the context of providing situational awareness of the battlefield, the effort to develop these (especially cognitive) functions will increase the ability to maintain awareness of already known facts (the situation), promptly carry out an initial assessment of the importance of the new information, understand this information in the context of the situation, anticipate the possible development of the situation with respect to the new information, and pass it on, in a comprehensible form and with a corresponding level

30 ENDSLEY, Mica R. Toward a Theory of Situation Awareness in Dynamic Systems. Human Factors: The Journal of the Human Factors and Ergonomics Society [online]. 1995, 37(1), 32-64 [cit. 2020-03-12]. ISSN 0018-7208. Available at: http://journals.sagepub.com/doi/10.1518/001872095779049543, p. 35, modified by the author. 
of detail, for its further use. To implement specific activities to develop these and many other skills, those findings of the "Cognitive Enhancement" 31 that fall into cognitive psychology or neuropsychology can be used. Considerable effort has already been made in this area within both the military theory ${ }^{32}$ and practice ${ }^{33}$, and its results can be used as a source of inspiration or a basis for possible further research or practical implementation of appropriate enhancement activities.

\section{CONCLUSION}

The dynamic development of the information environment affects all aspects of situational awareness, the considerable importance of which will increase even further in future operations. In order for Joint Task Force Headquarters to be able to provide thorough and accurate situational awareness and to share it effectively across operational domains, it is essential to understand this environment, monitor its development and continuously strive to develop the situational awareness capability accordingly.

To generate and maintain situational awareness, current and future operations cannot do without advanced information technology capable of processing and analysing a vast amount of data from the battlefield, sharing the respective derived information in real time across operational domains, and ensuring their ceaseless protection. However, for the effective use of advanced information technology it is necessary to adapt the settings of the internal operation-related information management processes, and more importantly, to develop the skills of the personnel to work with this technology, its products and information itself. This will be essential to understand the information in the context of the current situation not only within the respective domain but also in general, joint perspective, and to anticipate the impact of these facts on the future situation. More than on technical skills, it is thus particularly important to focus

31 "Cognitive Enhancement" is a discipline that deals with the possible enhancement of the brain performance for the purpose of improving cognitive functions. Although pharmaceuticals are often used in this context, and a considerable attention is being focused on interconnecting advanced technology with, or even its implantation inside the human body, a number of "non-invasive" psychological or neurological techniques is being used, ranging from common "brain training" exercises to meditation to specialized exercises using modifiable simulations of work-related tasks.

32 See BRUNYÉ, Tad T., Randy BROU, Tracy Jill DOTY, Frederick D. GREGORY, Erika K. HUSSEY, Harris R. LIEBERMAN, Kari L. LOVERRO, Elizabeth S. MEZZACAPPA, William H. NEUMEIER, et al. A Review of US Army Research Contributing to Cognitive Enhancement in Military Contexts. Journal of Cognitive Enhancement [online]. [cit. 2020-04-19]. DOI: 10.1007/s41465-020-00167-3. ISSN 2509-3290. Dostupné z: http://link. springer.com/10.1007/s41465-020-00167-3.

33 See BAUCOME, Randal G. Military Intelligence Soldiers Receive Cognitive Enhancement. U.S. Army [online]. August 18, 2017 [cit. 2020-04-19]. Dostupné z: https://www.army.mil/article/192624/ military_intelligence_soldiers_receive_cognitive_enhancement.

See USASOC Public Affairs. U.S. Army Special Operations Command rolls out new strategy. U.S. Army [online]. October 17, 2019 [cit. 2020-04-19]. Dostupné z: https://www.army.mil/article/228605/ us_army_special_operations_command_rolls_out_new_strategy. 
on a comprehensive and a time-consuming effort of the cognitive development of the personnel.

Lastly, providing situational awareness at the operational level will also be shaped, in a very specific way, by operations conducted in cyberspace. In addition to developing the technical capacities of the headquarters and the skills of "cyber personnel" to interpret the situation in this space intelligibly, it is necessary to ensure that "non-cyber personnel" have a general understanding of the cyber activities which will allow them to comprehend the situation in cyberspace in the context of overall, joint situational awareness to support well-informed decision-making in operations.

Author: $\quad$ MAJ Marek Fiebich, M.A., born in 1983. Graduated from the University of Defence in Brno (2008), the Metropolitan University Prague (2010) and the University of Leicester, UK (2016). From 2008 to 2013, he served at different land forces units within military intelligence and operations. In 2010, he was deployed to ISAF, Afghanistan, as a military intelligence officer. From 2013 to 2016, he served at the Multinational Joint Headquarters UIm, Germany, as a combined joint operations centre officer. After his return in 2016, he was appointed to the Land Forces Command Operations Directorate. From 2018, he serves at the Department of Military Strategic Studies of the Centre for Security and Military Strategic Studies in Brno. He deals with operational art and operational environment.

How to cite:FIEBICH Marek. Situational Awareness and Current Information Environment. Vojenské rozhledy. 2020, 29 (3), 025-040. ISSN 1210-3292 (print), 2336-2995 (online). Available at: www.vojenskerozhledy.cz 